\title{
On Some Issues Promoting Successful Second Language Learning and Teaching
}

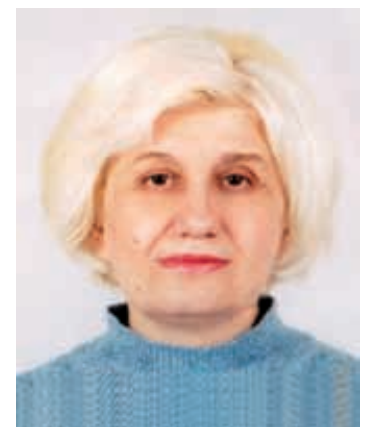

Anahit Zatikian

7 his paper is concerned with some means of facilitating

1 successful second or foreign language learning and teaching. It indicates that: a) a favourable attitude and a high level of motivation go hand in hand with successful learning; b) in the foreign language classroom the employment of authentic texts is effective; c) autonomy is one of the necessary conditions for successful language learning.

The article also aims at emphasizing the crucial importance of language learning strategies in foreign language learning and the teacher's role in strategy training.

\section{Motivation}

Second language acquisition is a complicated psycholinguistic process. The success of this process depends crucially on a well-organized schedule of learning, on the activity of its participants, i.e. learners and teachers, and also on the creation of conditions that feed the natural learning process. The role of motivation is very important in facilitating successful second language learning. Positive attitudes are conducive to increased motivation, while negative attitudes have the opposite effect.

Research tends to confirm that a favourable attitude and a high level of motivation go hand in hand with second-language learning success. According to most scholars, motivation is one of the key factors that influence the rate and success of second or foreign language learning. The learner's psychological state in second language learning is crucial. The positive influence of motivation on the psychological state of learners ensures success. Experience has shown that the best success is achieved by those learners who are the most motivated. Psychological preparation, predisposition, positive motivation and successful learning are closely interrelated. This can be shown graphically.

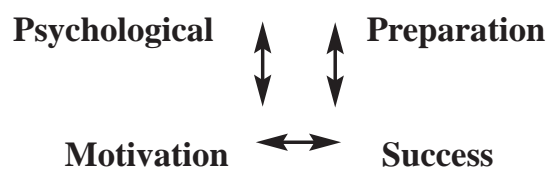


In language learning people are motivated in different ways and to different degrees, depending on their goals and attitude to language learning.

The establishment of a positive and friendly relationship between learners and teachers and anong learners is significant in motivating students. The teacher's role is crucial in motivating students. It is from the skills of professional teachers that positive emotions and attitudes towards the target language arise. Only successful teachers can raise the degree of motivation, convince learners of their abilities, and thus ensure success. It requires a great deal of effort and tact from teachers to help their learners to accept advice. As a matter of principle, learners should be encouraged to observe themselves as they use their target language, noting the circumstances in which they succeed and those in which they have difficulties, and exploring why the difficulties arise. Learners should be convinced that their failures and shortcomings can be ascribed to a lack of effective strategies rather than to a lack of potential. This encouragement should be regarded as a necessary factor for the provision of both motivation and success. A teacher should be able to plan interesting sessions. An interesting session is a successful session. A session is a combination (sum-total) of various activities in a lighthearted and an easy-going atınosphere, aiming at raising the rate of motivation and the achievement of success.

Problem solving could be one of the various activities planned to motivate students, to seize their attention and at the same time to facilitate language acquisition. It also develops students' critical thinking abilities.

The employment of various games motivates students' interests in and association with the text, and improves thinking abilities.

\section{Authentic Texts}

The employment of authentic texts is crucial in communicative language teaching methodology. They are more interesting than texts which have been invented. Authentic texts are more likely to have acquisition-promoting content than invented texts. Common sense dictates that in the langtage classroom we should try to create conditions for learning which are as close as possible to those of natural acquisition.

In the foreign langlage classroom authentic texts are a substitute for the community of native speakers within which natural language acquisition occurs; the more authentic texts we provide our learners with, the more opportunities we shall create for successfu] acquisition to take place. Thus authentic texts create conditions that feed the natural learning process. The great virtue of using authentic texts as the basis of productive exercises is that they provide learners with thematic, discourse, grammatical and lexical frameworks within which to work.

Research shows that leamers are capable of much more creative work than is often supposed, always provided they are given time and space in which to leam. This means that work on authentic texts should be explicitly concerned to develop leamers' autonomy.

\section{Autonomy}

Autonomy is very important both as an educational goal and as a characteristic of learning in general and language learning in particular. Effective language learning 
depends on the extent to which learners achieve autonomy.

The autonomous language classroom or learning scheme will seek to create the conditions in which learning proceeds by negotiation, interaction and problem solving. The teacher's role is changed from purveyor of information to counsellor and manager of learning resources.

The benefits that should arise from the development of learner autonomy in adult education may be summarized as follows:

- because the learner sets the agenda, learning should be more effective both immediately and in the longer term;

- because responsibility for the learning process lies with the learner, the barriers between learning and living that are often found in traditional teacher-led educational structures should not arise;

- If there are no barriers between learning and living, learners should have little difficulty in transferring their capacity for autonomous behaviour to all other areas of their lives and this should make them more effective participants in the democratic process. Learners start to recognize their individuality, personality and feel independent and mature.

\section{The Importance of Language Learning Strategies}

\section{in Language Learning and Teaching}

Since the amount of information to be processed by language learners is high in the language classroom, learners use different language learning strategies in performing the tasks and processing the new input they face. Language learning strategies are good indicators of how learners approach tasks or problems encountered during the process of language learning. In other words, language learning strategies give language teachers valuable clues about how their students assess the situation, plan and select appropriate skills so as to understand, learn, or remember new input presented in the language classroom. According to Fedderholdt, the language learner capable of using a wide variety of language leaming strategies appropriately can improve his language skilts in a better way. Lessard-Clouston states that language learning strategies contribute to the development of the communicative competence of the students. Language teachers aiming at developing the communicative competence of the students and language learning should be familiar with language learning strategies. Besides developing the cornmunicative competence of the students, teachers who train students to use language learning stralegies can help them become better language learners. Helping students understand good language learning strategies and training them to develop and use such good language learning strategies can be regarded as the characteristics of a good language teacher. The teacher learns from his students as much as he tries to help them with English. It should be strongly siressed that using the same good language learning strategies does not guarantee that bad leamers will also become successful in language learning since other factors like age, gender, personality, motivation, self-concept, lifeexperience, learning style, excitement, anxiety may also play a role in success. 


\section{The Teacher's Role in Strategy Training}

The teacher should have adequate knowledge about the students, their goals, interests, motivations, language learning strategies, and their understanding of the course to be taught. It is a fact that each learner within the same classroom may have different learning styles and varied awareness of the use of strategies. The teacher cannot attribute importance to only one group and support the analytical approach or only give input by using the auditory mode. The language teacher should, therefore, provide a wide range of learning strategies in order to meet the needs and expectations of his students with their different learning styles, motivations, strategy preferences, etc. Therefore, the most important role of the teacher in foreign language teaching is the provision of a range of tasks to match varied learning styles.

The language teacher should look for new texts or other teaching materials if language learning strategies are not already included within his materials. Teachers should be flexible and creative. They should be constantly on the look-out to find new ways and methods to achieve effective language teaching.

It should be emphasized that questioning himself about what he plans to do before each lesson and evaluating his lesson plan after the lesson in terms of strategy training, the teacher can become better prepared to focus on language learning strategies and strategy training during the process of his teaching.

Hence, the effectiveness of the teaching process is closely connected with learner's behaviour and attitude and also with the matchmaking rechniques which will link learners and teachers with similar style and approaches to language learning.

\section{References:}

1. Lessard-Clouston, Michael, Language Learning Strategies: An Overview for L2 Teachers. 1997. http: // www. ITSLI.org

2. Fedderholdt, Karen. Using Diaries to Develop Language Learning Strategies. TESL. Vol. 3, № 12. December, 1997. http: // www. ITSL1.org

3. Hall, Stephen. Language Learning Strategies: From the Ideals to Classroom Tasks. Language and Communication Division, Temasek Polytechnic on Internet, 1997. http: // www. ITSLl.org

4. Oxford, Rebecca. Language Learning Strategies: What Every Teacher Should Know. New York, Newbury House Publishers, 1990.

5. Holec H. Autonomy in Foreign Language Learning. Oxford, 1981.

6. David Little, Sean Devitl and David Singleton. Authentic Texts in Foreign Language. Dublin, 1988. 


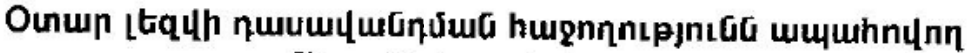 un puap hungtinh 2 nเn2}

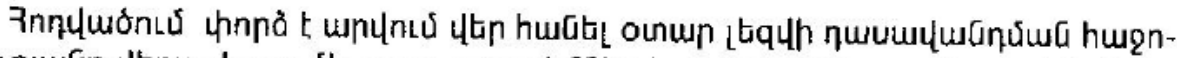

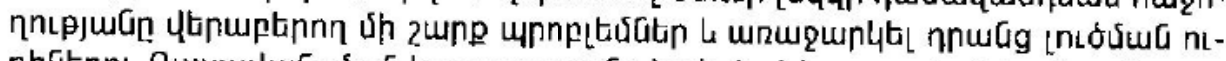



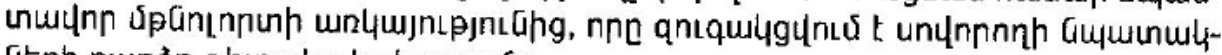
Gitnh punàn qhunuugumónıpjwúp:

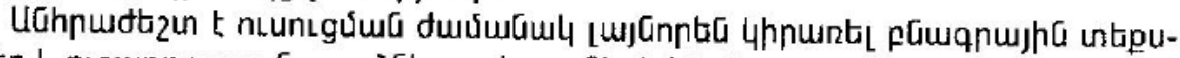

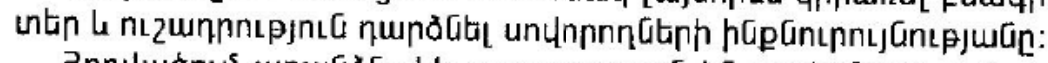

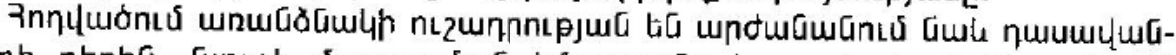

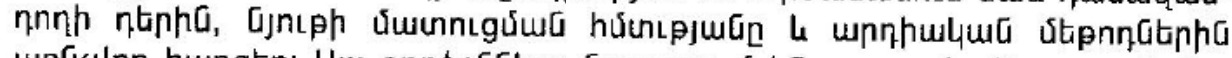

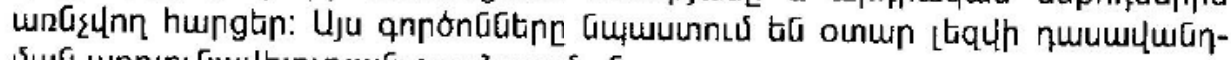

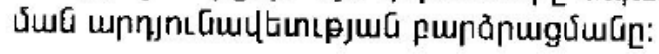

